\title{
Impact of the envelope design of residential buildings on their acclimation energy demand, $\mathrm{CO}_{2}$ emissions and energy rating
}

\author{
M. Carpio ${ }^{1}$, A. García-Maraver ${ }^{2}$, D. P. Ruiz ${ }^{3}$ \\ $\&$ M. Martín-Morales ${ }^{1}$ \\ ${ }^{1}$ Department of Building Construction, University of Granada, Spain \\ ${ }^{2}$ Department of Civil Engineering, University of Granada, Spain \\ ${ }^{3}$ Department of Applied Physics, University of Granada, Spain
}

\begin{abstract}
Building envelopes are the part of the buildings most exposed to the inclement weather and thus have significant impact on the energy performance as a consequence of higher thermal transfers produced. Therefore, new solutions for building envelopes are required as a way to save energy in residential buildings. In this regard, the European Directives 2002/91/EC and 2010/31/EU on Energy Performance of Buildings (EPBD) have laid down the application of minimum requirements to the energy performance of building elements that form part of the envelope. Designers require, in the early stages, a method to obtain information about the energy performance of the building, as design decisions made at this stage might compromise the performance of the final design. Among the possible energy-savings solutions the most effective are not only those related to the construction design but also those that consider constructive materials with low thermal transmittance. Consequently, the objective of this study is to analyze and compare, by means of energy simulations, different constructive solutions applied to the building envelopes in terms of construction design and constructive materials. The results obtained showed that the energy demand and $\mathrm{CO}_{2}$ emissions of residential buildings can be reduced by $60 \%$ and $95 \%$ respectively when constructive solutions with low U-values are implemented. These reductions make also possible the enhancement of the energy rating of the buildings.

Keywords: envelope, energy rating, buildings, $\mathrm{CO}_{2}$ emissions.
\end{abstract}




\section{Introduction}

Due to the fact that the building sector is a potentially large energy consumer, special attention has been paid in order to reduce its environmental impact $[1,2]$. Acclimation energy consumption of buildings is mainly affected by local climatic conditions, indoor temperature, shape factor, windows-to-wall ratio and building envelope performance. Therefore, new solutions for building envelopes are required because they are the part of the buildings most exposed to the inclement weather and thus where higher thermal transfers are produced. Accordingly, a proper design of the thermal properties of building envelopes would lead to energy-saving in residential buildings.

With this objective, the European Union has created a legislative framework for all its member countries based on the Kyoto Protocol [3] and the Directives 2002/91/EC [1] and 2010/31/EU [2] on Energy Performance of Buildings (EPBD). These regulations have laid down the application of "minimum requirements to the energy performance of building elements that form part of the building envelope and that have a significant impact on the energy performance of the building envelope when they are retrofitted or replaced". However, it is important to highlight the existence of different transpositions of the EPBD for each European country (EU-28 and Norway), which means that there are different regulations but with the common objective of achieving a Nearly Zero-Energy Building (NZEB) able to combine both comfort and minimum energy consumption [4].

Besides having to comply with regulations on energy performance, buildings have long life cycles and are potentially large energy consumers. As a consequence, several studies on energy efficiency of existent buildings have been performed [5-11]. These studies have primarily focused on the improvement of the energy efficiency of currently existing envelopes in private and public buildings considering the weather as much in summer as in winter. Nevertheless, the construction techniques to improve an existent envelope differ from those that can be applied to new construction units.

Considering this point, the aim of the present study is to study how the different constructive solutions affect the thermal envelope of residential buildings under different climate conditions. In addition, it analyses the influence of the thermal envelope design in the energy demand, $\mathrm{CO}_{2}$ emissions and energy rating of two different types of buildings located in six climatic zones.

\section{Material and methods}

\subsection{Envelope of the buildings}

\subsubsection{Composition}

The thermal envelope of a building is composed by the elements represented in Fig. 1, which includes all the enclosures that mark out the habitable spaces from the outside, and the interior partitions, which demarcate the living spaces from the non-habitable spaces in contact with the outside [12]. 


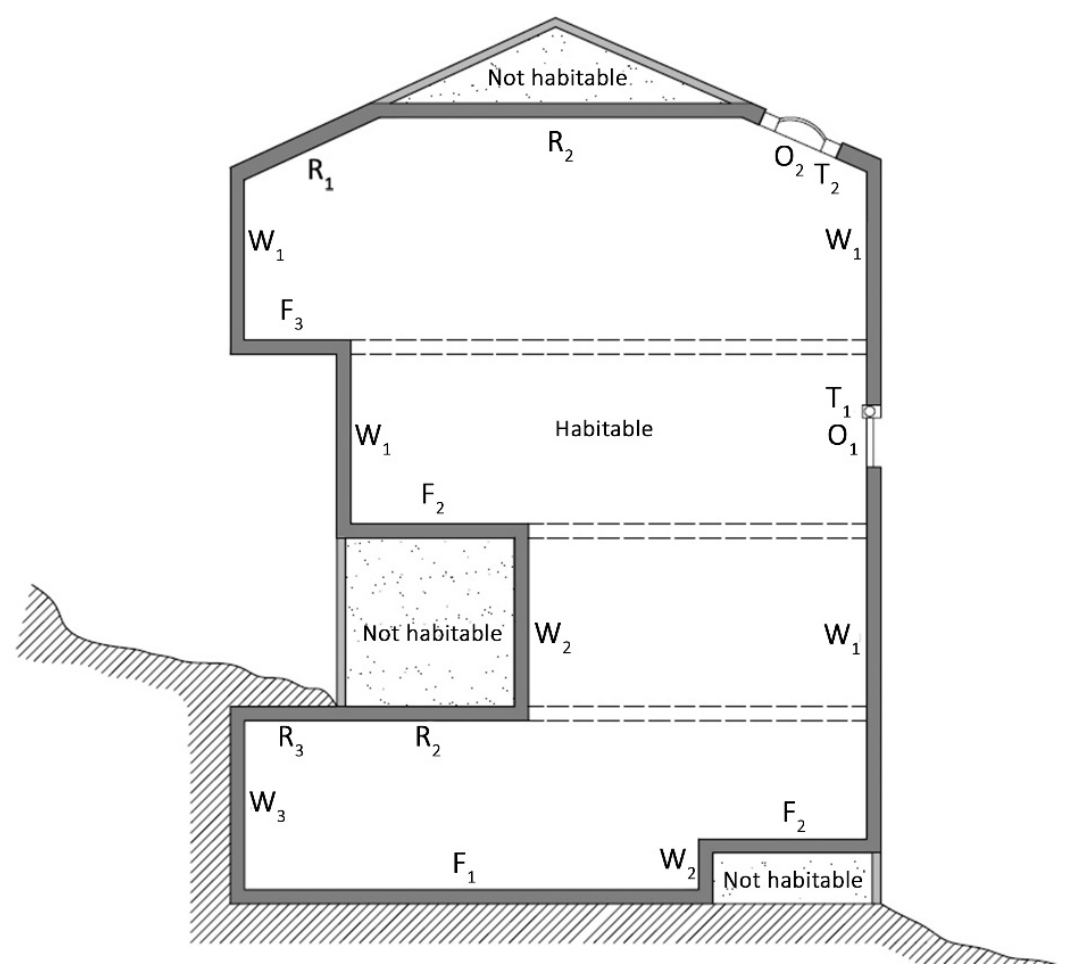

Figure 1: Composition of the thermal envelope of a building: Vertical external walls (W); Horizontal roofs (R); Floors (F); Openings (O); and Thermal bridges (T) [13].

\subsubsection{Thermal transmittance}

Thermal transmittance, also known as U-value, is defined as the rate of transfer of heat under uniform conditions through one square metre of a structure, divided by the difference in temperature across the structure (the lower the U-value, the better the insulating ability). It is expressed in $\mathrm{W} / \mathrm{m}^{2} \mathrm{~K}$ and can be calculated by eqns. (1) and (2), where: $R_{s i}$ is the inside resistance; $R_{s e}$ is the external resistance; and $R_{t}$ is the thermal resistance of the construction material $\left(\mathrm{m}^{2} \mathrm{~K} / \mathrm{W}\right)$, which is formed by thermally homogeneous layers with their own resistances $\left(R_{1}, R_{2} \ldots R_{n}\right)$.

$$
\begin{gathered}
U=\frac{1}{R_{s i}+R_{t}+R_{s e}} \\
R_{t}=R_{1}+R_{2}+R_{3}+\ldots+R_{n}
\end{gathered}
$$


$\mathrm{R}$-value is the thermal resistance of a solid material to conductive heat transfer (the higher the number, the better the building insulation's theoretical effectiveness).

$$
R=\frac{e}{\lambda}
$$

This energy flow is produced when there is a difference between the inside temperature and the temperature outside, and can be calculated by eqn. (3), where: $e$ is the thickness of the material (m); and $\lambda$ is the thermal conductivity $(\mathrm{W} / \mathrm{mK})$.

\subsection{Buildings characteristics}

\subsubsection{Description of buildings}

Two types of buildings were selected to develop this study: (i) a single-family house; and (ii) a multi-family residential building placed among other constructions.

The single-family dwelling consists of three floors with total usable area 261.99 $\mathrm{m}^{2}$ : a basement $\left(108.73 \mathrm{~m}^{2}\right)$, a ground floor $\left(117.01 \mathrm{~m}^{2}\right)$ and a first floor $\left(36.25 \mathrm{~m}^{2}\right)$. The house is located on a gentle slope, which means that the basement is completely underground on one side, yet above the ground on the other side of the house.

The multi-family dwelling has five stories with total usable area $861.71 \mathrm{~m}^{2}$ : a ground floor $\left(267.10 \mathrm{~m}^{2}\right)$, a first $\left(267.10 \mathrm{~m}^{2}\right)$, a second $\left(267.10 \mathrm{~m}^{2}\right)$, a third floor $\left(267.10 \mathrm{~m}^{2}\right)$, and a tower $\left(18.96 \mathrm{~m}^{2}\right)$. In this case, the building is a rectangle on a corner so that the north and east sides of it are fully in contact with other constructions, while the south and west façades are exposed.

For the thermal simulation of each building and climatic zone, boilers with similar characteristics were chosen. The fuel in all boilers is biomass. The thermal load selected for each boiler was set to $24 \mathrm{~kW}$. For the single-family house, just one boiler $(24 \mathrm{~kW})$ was considered, whereas for the multi-family dwelling three boilers were installed (total boiler load of $72 \mathrm{~kW}$ ). For all boilers, the thermal efficiency value adopted was $90 \%$, with an outlet water temperature of $50^{\circ} \mathrm{C}$ for domestic hot water (DHW) and $80^{\circ} \mathrm{C}$ for heating. The flow rate of DHW in the single-family house was 235.80 liters/day, and in the multi-family dwelling 568.72 liters/day. Both types of residence featured an accumulator; specifically, it had a capacity of 200 liters in the single-family house and 500 liters in the multi-family dwelling. In both cases the water temperature varied between $60^{\circ} \mathrm{C}$ and $80^{\circ} \mathrm{C}$, the global heat transfer coefficient $(\mathrm{U} \times \mathrm{A})$ was $1 \mathrm{~W} / \mathrm{K}$.

\subsubsection{Constructive solutions}

Three different solutions have been studied to define the thermal envelope of the buildings previously described (Tables 1 and 2 and Fig. 2). Considering the thermal transmittance mentioned in section 2.1.2, Solution 1 was that with the highest thermal transmittance, followed by Solution 2 and being Solution 3 the constructive solution with lower U-value. 
Table 1: Elements and materials used. Thermal characteristics.

\begin{tabular}{|c|c|c|c|c|c|}
\hline & & Material & $e$ & $\lambda$ & $\mathrm{R}$ \\
\hline \multirow{14}{*}{ 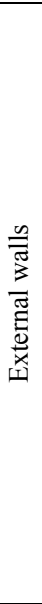 } & \multirow{4}{*}{ 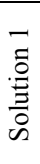 } & Lime mortar for rendering $1000<\mathrm{d}<1250$ & 0.015 & 0.550 & 0.027 \\
\hline & & 12 in. perforated metric brick $40 \mathrm{~mm}<\mathrm{G}<50 \mathrm{~mm}$ & 0.240 & 1.529 & 0.157 \\
\hline & & Plaster rendering $1000<\mathrm{d}<1300$ & 0.015 & 0.570 & 0.026 \\
\hline & & $\mathrm{U}=2.63 \mathrm{~W} / \mathrm{m}^{2} \mathrm{~K}$ & 0.270 & & \\
\hline & \multirow{4}{*}{ 奋 } & Lime mortar for rendering $\mathrm{d}>2000$ & 0.015 & 1.800 & 0.008 \\
\hline & & Thermal blocks & 0.290 & 0.426 & 0.681 \\
\hline & & Plaster rendering $1000<\mathrm{d}<1300$ & 0.015 & 0.570 & 0.026 \\
\hline & & $\mathrm{U}=1.13 \mathrm{~W} / \mathrm{m} 2 \mathrm{~K}$ & 0.320 & & \\
\hline & \multirow{6}{*}{ 奋 } & 6 in. perforated metric brick $40 \mathrm{~mm}<\mathrm{G}<50 \mathrm{~mm}$ & 0.115 & 0.991 & 0.116 \\
\hline & & Lime mortar for rendering $1000<\mathrm{d}<1250$ & 0.015 & 0.550 & 0.027 \\
\hline & & Expanded polystyrene [EPS] [0.037 W/[m K]] & 0.080 & 0.037 & 2.162 \\
\hline & & $\begin{array}{l}\text { Double hollow brick breeze-block }[60 \mathrm{~mm}<\mathrm{E}<90 \\
\mathrm{mm}]\end{array}$ & 0.075 & 0.432 & 0.174 \\
\hline & & Plaster rendering $1000<\mathrm{d}<1300$ & 0.015 & 0.570 & 0.026 \\
\hline & & $\mathrm{U}=0.37 \mathrm{~W} / \mathrm{m}^{2} \mathrm{~K}$ & 0.300 & & \\
\hline \multirow{24}{*}{$\begin{array}{l}\frac{1}{0} \\
\stackrel{0}{2}\end{array}$} & \multirow{5}{*}{ 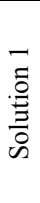 } & Ceramic tiles & 0.006 & 1.000 & 0.006 \\
\hline & & Lime mortar for rendering $\mathrm{d}>2000$ & 0.024 & 1.800 & 0.013 \\
\hline & & Floor structure & 0.250 & 1.154 & 0.217 \\
\hline & & Plaster rendering $1000<\mathrm{d}<1300$ & 0.015 & 0.570 & 0.026 \\
\hline & & $\mathrm{U}=2.49 \mathrm{~W} / \mathrm{m}^{2} \mathrm{~K}$ & 0.295 & & \\
\hline & \multirow{9}{*}{$\begin{array}{l}\text { N } \\
\stackrel{0}{0} \\
\text { 苛 } \\
\stackrel{\circ}{\circ}\end{array}$} & Ceramic tiles & 0.006 & 1.000 & 0.006 \\
\hline & & Lime mortar for rendering $\mathrm{d}>2000$ & 0.024 & 1.800 & 0.013 \\
\hline & & Mortar lightweight aggregate [vermiculite perlite] & 0.040 & 0.410 & 0.098 \\
\hline & & Polyvinyl chloride [PVC] & 0.001 & 0.170 & 0.006 \\
\hline & & Ceramic tiles & 0.030 & 1.000 & 0.030 \\
\hline & & Slightly ventilated air chamber & 0.100 & 0.000 & 0.000 \\
\hline & & Floor structure & 0.300 & 1.304 & 0.230 \\
\hline & & Plaster rendering $1000<\mathrm{d}<1300$ & 0.015 & 0.570 & 0.026 \\
\hline & & $\mathrm{U}=1.56 \mathrm{~W} / \mathrm{m}^{2} \mathrm{~K}$ & 0.516 & & \\
\hline & \multirow{10}{*}{$\begin{array}{l}\stackrel{n}{\Xi} \\
\stackrel{0}{0} \\
\stackrel{0}{0} \\
\mathscr{\infty}\end{array}$} & Sand and gravel $[1700<\mathrm{d}<2200]$ & 0.050 & 2.000 & 0.025 \\
\hline & & Sublayer felt & 0.001 & 0.050 & 0.020 \\
\hline & & Polyvinyl chloride [PVC] & 0.001 & 0.170 & 0.006 \\
\hline & & Sublayer felt & 0.001 & 0.050 & 0.020 \\
\hline & & $\begin{array}{l}\text { Extruded polystyrene, expanded with carbon dioxide } \\
{[\mathrm{XPS}][0.034 \mathrm{~W} /[\mathrm{m} \mathrm{K}]]}\end{array}$ & 0.060 & 0.034 & 1.765 \\
\hline & & Low density polyethylene [LDPE] & 0.002 & 0.330 & 0.006 \\
\hline & & Concrete with lightweight aggregate $1800<\mathrm{d}<2000$ & 0.100 & 1.350 & 0.074 \\
\hline & & Floor structure & 0.250 & 0.256 & 0.977 \\
\hline & & Plaster rendering $1000<\mathrm{d}<1300$ & 0.015 & 0.570 & 0.026 \\
\hline & & $\mathrm{U}=0.33 \mathrm{~W} / \mathrm{m}^{2} \mathrm{~K}$ & 0.480 & & \\
\hline
\end{tabular}

$e(m m) ; \lambda(W / m K) ; R\left(m^{2} K / W\right)$ 


\section{External walls}

Roofs

\section{Solution 1}
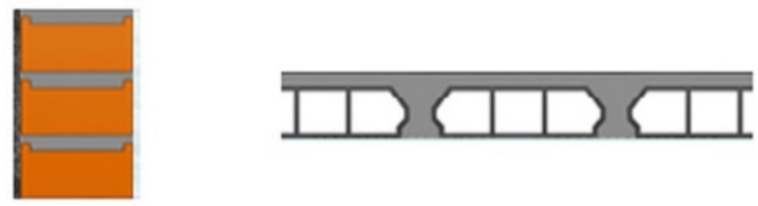

Solution 2
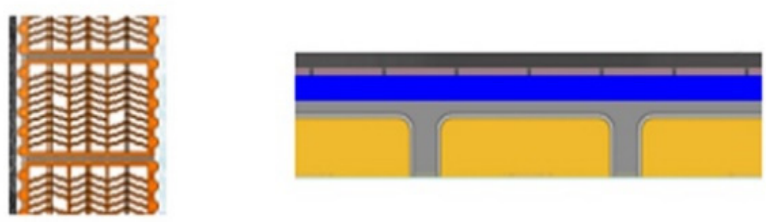

Solution 3
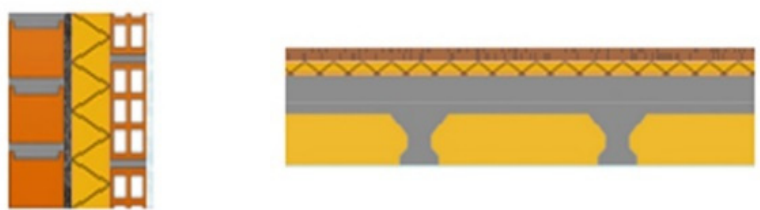

Figure 2: Elements and materials used. Graphic details.

Table 2: External openings. Thermal characteristics.

\begin{tabular}{|c|c|c|}
\hline & Material & $\mathrm{U}\left(\mathrm{W} / \mathrm{m}^{2} \mathrm{~K}\right)$ \\
\hline \multirow{3}{*}{ 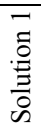 } & Glass (85\%): Monolithic (4) & 5.700 \\
\hline & Frame $(15 \%)$ : Metallic without thermal break & 5.700 \\
\hline & Total & 5.700 \\
\hline \multirow{3}{*}{ 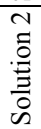 } & Glass $(85 \%)$ : Double $(4-6-4)$ & 3.300 \\
\hline & Frame (15\%): Low density wood & 2.000 \\
\hline & \begin{tabular}{|c|} 
Total \\
\end{tabular} & 3.170 \\
\hline \multirow{3}{*}{ 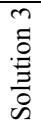 } & Glass $(85 \%)$ : Double low-e $<0.03(4-9-4)$ & 1.900 \\
\hline & Frame (15\%): Three chambers PVC & 1.800 \\
\hline & Total & 1.880 \\
\hline
\end{tabular}

\subsubsection{Climatic zones}

In this study, the most common climatic zones in Spain were selected [13, 14], because of including extremes zones (A4 and B3 as the warmest, and D2 and E1 as the coldest) and intermediate zones ( $\mathrm{C} 4$ and $\mathrm{C} 3$ ). 


\subsection{Simulation software}

The energy simulation software solutions available nowadays differ in terms of how the characteristics of the building are introduced as input, and also in the output supplied [15], but all providing valid results. In this study, CERMA [16] has been chosen as the simulation software. This software calculates the energy demand, the $\mathrm{CO}_{2}$ emissions and the energy rating basing on the constructive solutions, buildings design and location.

Regarding the energy rating, this program works on the scale of seven levels [13], which are represented in Fig. 3.

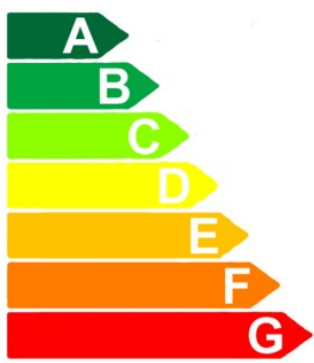

Figure 3: Energy rating. Scale of seven levels [13].

\section{Results and discussion}

Table 3 and Figs 4 and 5 show the energy demand, $\mathrm{CO}_{2}$ emissions and energy rating, which are dependent on: the envelope design of the constructive solution; the type of building (single-family or multi-family); and the climatic zone where the building is located.

\subsection{Energy demand}

Fig. 4 shows that the total energy demand ranged from $42.9 \mathrm{kWh} / \mathrm{m}^{2}$ year in a multi-family building located in the climatic zone A4 with Solution 3 as a constructive solution, to $356.2 \mathrm{kWh} / \mathrm{m}^{2}$ year in a single-family house with Solution 1 located in E1.

The results have revealed that A4 was the climate zone that required a lower total energy demand with any constructive solution in the both types of buildings studied. On the contrary, E1 was the climate zone that higher total energy demand required.

Regarding the envelope design characteristics of the different constructive solutions considered, and owing to the low thermal transmittance values of solution 3 (Table 1), it was the constructive solution with the lowest energy demand for the types of buildings studied. 
In the case of the single-family house, the implementation of Solution 2 supposed an increase of $49 \%-62 \%$ with respect to the energy demand required with Solution 3, and the same house with Solution 1 increased its energy demand within the range $130 \%-171 \%$ depending on the climate zone. When the multifamily building was considered, the use of the constructive Solution 2 resulted in an increment of its energy demand from $45 \%$ to $60 \%$, and $109 \%-143 \%$ was the growth in case of implementing Solution 1 in comparison with Solution 3 (Fig. 4).

In general, the single-family house was the building that obtained larger improvement because of having more envelope surface per $\mathrm{m}^{2}$ and thus more surface to be improved by constructive solutions.

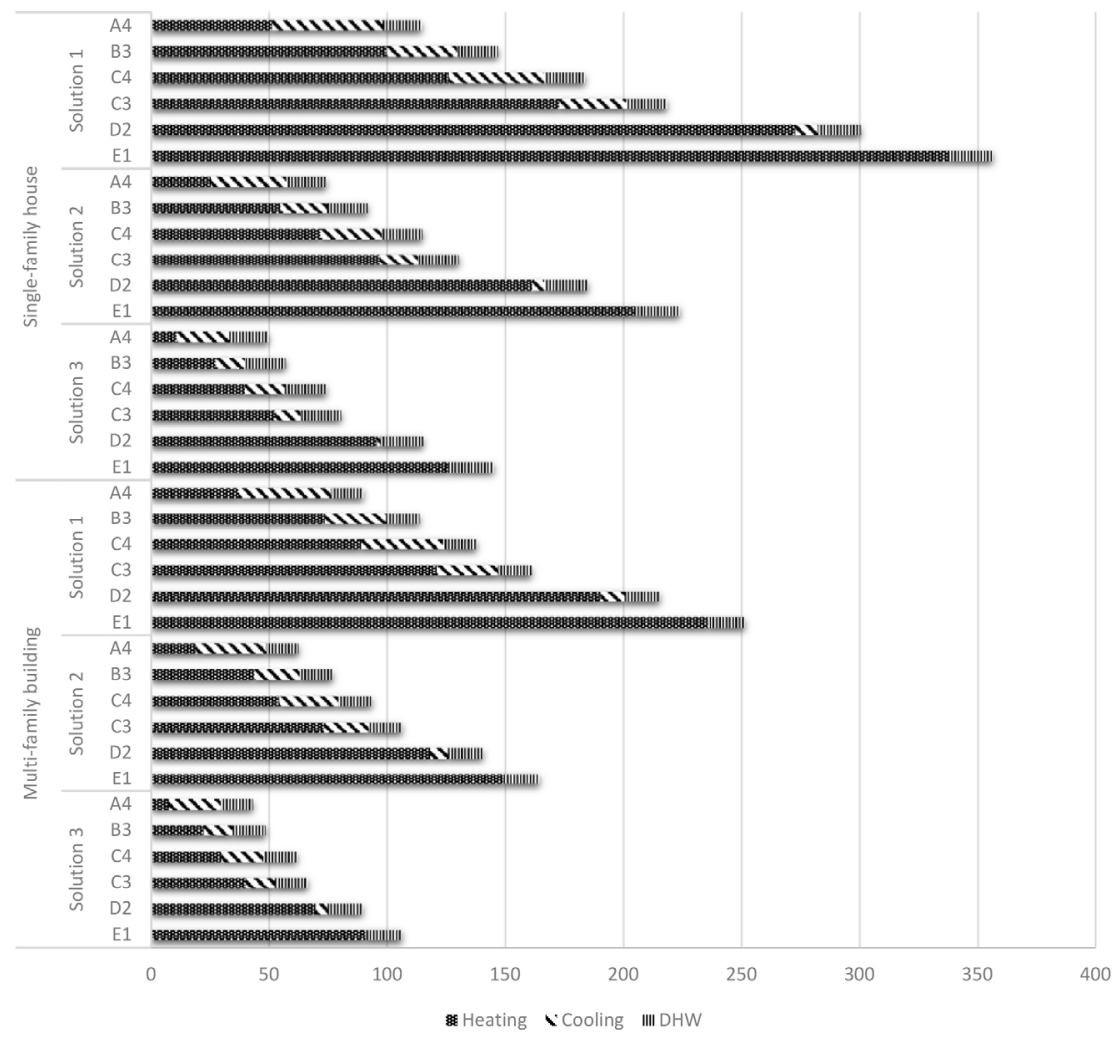

Figure 4: Energy demand $\left(\mathrm{kWh} / \mathrm{m}^{2}\right.$ per year $)$.

\section{2 $\mathrm{CO}_{2}$ emissions and energy rating}

Taking into account that the building sector represents $40 \%$ of the energy consumption and $36 \%$ of the $\mathrm{CO}_{2}$ emissions in Europe $[1,2]$, the use of energyefficient materials in the thermal envelopes of buildings leads not only to a reduction of the energy demanded, but also to a significant reduction of the environmental impact derived from this sector. 
Table 3 and Fig. 5 show the $\mathrm{CO}_{2}$ emissions generated as a consequence of the energy demanded. In this section, and due to the fact that the energy consumption for DHW production is associated with the energy produced for heating because of using the same boiler, both were considered as a whole.

In order to discuss the results obtained, Solution 3 was considered as the point of reference because of being the optimum constructive solution (with minimum energy demand and near-zero emissions). From this point, it was observed that the use of Solution 2 resulted in an increase of 44\%-300\% regarding the $\mathrm{CO}_{2}$ emissions generated in the single-family house, whereas this increment varied between $41 \%$ and $68 \%$ when the multi-family building was considered (Fig. 5).

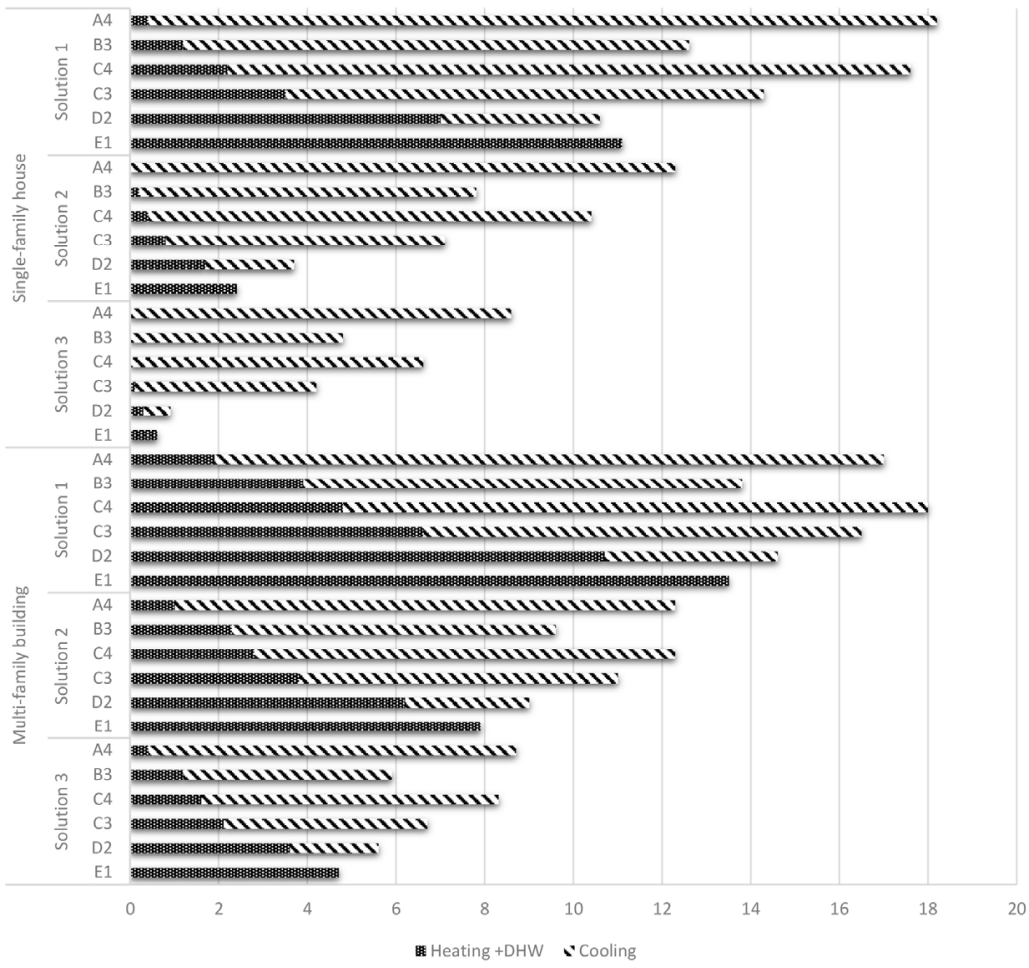

Figure 5: $\mathrm{CO}_{2}$ emissions $\left(\mathrm{kgCO}_{2} / \mathrm{m}^{2}\right.$ per year $)$.

The higher values of the intervals corresponded to the coldest areas (E1), while on the contrary the minimum values of increment were achieved in the warmest climate zones (Table 3). These ranges were substantially enlarged when the Solution 1 was implemented, achieving $112 \%-1,750 \%$ of increment in the case of the $\mathrm{CO}_{2}$ emissions generated in the single-family house and corresponding the major percentage to the house located in the climatic zone E1.

As observed with Solution 2, the ranges of increment were also reduced for Solution 1 when the multi-family building was analyzed, being the growth of $\mathrm{CO}_{2}$ emissions within $95 \%-187 \%$. 
As in the case of the energy demand, larger reductions in $\mathrm{CO}_{2}$ emissions are achieved in the case of the single-family house because of having more envelope surface to be improved by constructive solutions.

On the other hand, and because of the existent relationship between the $\mathrm{CO}_{2}$ emissions and the energy rating of the buildings [13], a higher quality of the materials used in the envelope of a building led to higher energy ratings. As shown in Table 3, the use of the Solution 3 entailed the obtaining of two positive energy rating levels in both types of buildings in comparison with the energy ratings that resulted from the use of Solution 1.

Table 3: Energy demand, $\mathrm{CO}_{2}$ emissions and energy rating.

\begin{tabular}{|c|c|c|c|c|c|c|c|c|c|c|}
\hline & \multirow[t]{2}{*}{$\mathrm{CZ}$} & \multicolumn{4}{|c|}{$\begin{array}{l}\text { Energy demand } \\
\left(\mathrm{kWh} / \mathrm{m}^{2} \text { per year) }\right.\end{array}$} & \multicolumn{4}{|c|}{$\begin{array}{c}\mathrm{CO}_{2} \text { emissions } \\
\left(\mathrm{kg} \mathrm{CO}_{2} / \mathrm{m}^{2} \text { per year }\right)\end{array}$} \\
\hline & & & Heating & Cooling & DHW & Total & Heating + DHW & Cooling & Total & ER \\
\hline \multirow{18}{*}{ 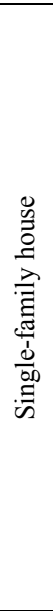 } & \multirow{6}{*}{ 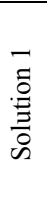 } & A4 & 51.2 & 46.7 & 16.6 & 114.5 & 0.4 & 17.8 & 18.2 & $\mathrm{D}$ \\
\hline & & B3 & 99.6 & 30.0 & 17.1 & 146.7 & 1.2 & 11.4 & 12.7 & $\mathrm{C}$ \\
\hline & & $\mathrm{C} 4$ & 126.0 & 40.4 & 17.2 & 183.6 & 2.2 & 15.4 & 17.6 & $\mathrm{C}$ \\
\hline & & $\mathrm{C} 3$ & 172.6 & 28.4 & 17.1 & 218.1 & 3.5 & 10.8 & 14.3 & $\mathrm{C}$ \\
\hline & & D2 & 272.6 & 9.5 & 18.2 & 300.3 & 7.0 & 3.6 & 10.6 & A \\
\hline & & E1 & 337.4 & 0.0 & 18.8 & 356.2 & 11.1 & 0.0 & 11.1 & A \\
\hline & \multirow{6}{*}{$\begin{array}{l}\text { N } \\
\stackrel{0}{0} \\
\stackrel{0}{\Xi} \\
\dot{0} \\
\mathscr{n}\end{array}$} & A4 & 25.1 & 32.2 & 16.6 & 73.9 & 0.0 & 12.3 & 12.4 & $\mathrm{C}$ \\
\hline & & B3 & 54.6 & 19.8 & 17.1 & 91.5 & 0.2 & 7.6 & 7.8 & $\mathrm{~B}$ \\
\hline & & $\mathrm{C} 4$ & 71.6 & 26.1 & 17.2 & 114.9 & 0.4 & 10.0 & 10.4 & B \\
\hline & & $\mathrm{C} 3$ & 96.6 & 16.4 & 17.1 & 130.1 & 0.8 & 6.3 & 7.1 & A \\
\hline & & $\mathrm{D} 2$ & 161.3 & 5.1 & 18.2 & 184.6 & 1.7 & 2.0 & 3.6 & A \\
\hline & & E1 & 204.7 & 0.0 & 18.8 & 223.5 & 2.4 & 0.0 & 2.4 & A \\
\hline & \multirow{6}{*}{$\begin{array}{l}\stackrel{n}{\Xi} \\
\stackrel{0}{\Xi} \\
\stackrel{0}{0} \\
\mathscr{n}\end{array}$} & A4 & 10.5 & 22.6 & 16.6 & 49.7 & 0.0 & 8.6 & 8.6 & $\mathrm{C}$ \\
\hline & & B3 & 27.3 & 12.5 & 17.1 & 56.9 & 0.0 & 4.8 & 4.8 & A \\
\hline & & $\mathrm{C} 4$ & 39.5 & 17.2 & 17.2 & 73.9 & 0.0 & 6.6 & 6.6 & A \\
\hline & & $\mathrm{C} 3$ & 52.4 & 10.9 & 17.1 & 80.4 & 0.1 & 4.1 & 4.2 & A \\
\hline & & D2 & 95.4 & 1.5 & 18.2 & 115.1 & 0.3 & 0.6 & 0.9 & A \\
\hline & & E1 & 126.2 & 0.0 & 18.8 & 145.0 & 0.6 & 0.0 & 0.6 & $\mathrm{~A}$ \\
\hline \multirow{18}{*}{ 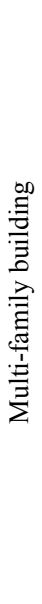 } & \multirow{6}{*}{ 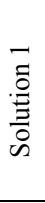 } & A4 & 36.8 & 39.4 & 13.6 & 89.8 & 1.9 & 15.1 & 17.0 & E \\
\hline & & B3 & $\begin{array}{l}73.6 \\
\end{array}$ & 25.9 & 14.0 & 113.5 & 3.9 & 9.9 & $\begin{array}{ll}13.8 \\
\end{array}$ & $\mathrm{D}$ \\
\hline & & $\mathrm{C} 4$ & 88.8 & 34.7 & 14.1 & 137.6 & 4.8 & 13.2 & 18.0 & $\mathrm{D}$ \\
\hline & & $\mathrm{C} 3$ & 120.8 & 26.0 & 14.0 & 160.8 & 6.6 & 9.9 & 16.5 & $\mathrm{D}$ \\
\hline & & $\mathrm{D} 2$ & 190.2 & 10.2 & 14.8 & 215.2 & 10.7 & 3.9 & 14.6 & $\mathrm{C}$ \\
\hline & & E1 & 235.6 & 0.0 & 15.3 & 250.9 & 13.5 & 0.0 & 13.5 & B \\
\hline & \multirow{6}{*}{ 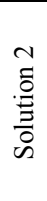 } & A4 & 18.9 & 29.7 & 13.6 & 62.2 & 1.0 & 11.3 & 12.3 & D \\
\hline & & B3 & 43.7 & 19.1 & 14.0 & 76.8 & 2.3 & 7.3 & 9.6 & $\mathrm{C}$ \\
\hline & & C4 & 54.2 & 24.9 & 14.1 & 93.2 & 2.8 & 9.5 & 12.3 & $\mathrm{C}$ \\
\hline & & $\mathrm{C} 3$ & 73.2 & 18.8 & 14.0 & 106.0 & 3.8 & 7.2 & 11.0 & $\mathrm{C}$ \\
\hline & & D2 & 118.2 & 7.3 & 14.8 & 140.3 & 6.2 & 2.8 & 9.0 & B \\
\hline & & E1 & 148.9 & 0.0 & 15.3 & 164.2 & 7.9 & 0.0 & 7.9 & $\mathrm{~A}$ \\
\hline & \multirow{6}{*}{ 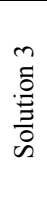 } & A4 & 7.5 & 21.8 & 13.6 & 42.9 & 0.4 & 8.3 & 8.7 & $\mathrm{C}$ \\
\hline & & B3 & 22.1 & 12.3 & 14.0 & 48.4 & 1.2 & 4.7 & 5.9 & B \\
\hline & & $\mathrm{C} 4$ & 29.8 & 17.6 & 14.1 & 61.5 & 1.6 & 6.7 & 8.3 & B \\
\hline & & C3 & 40.0 & 12.2 & 14.0 & 66.2 & 2.1 & 4.6 & 6.7 & B \\
\hline & & D2 & 69.4 & 5.2 & 14.8 & 89.4 & 3.6 & 2.0 & 5.6 & $\mathrm{~A}$ \\
\hline & & E1 & 90.6 & 0.0 & 15.3 & 105.9 & 4.7 & 0.0 & 4.7 & A \\
\hline
\end{tabular}

CZ: Climatic zone; ER: Energy rating 


\section{Conclusions}

This study has demonstrated that an appropriate envelope design of buildings implies important advantages such as the following: (i) reduction of the total energy demand; (ii) reduction of $\mathrm{CO}_{2}$ emissions to the atmosphere; (iii) higher energy rating.

The use of constructive solutions with high values of thermal transmittance could require from $179 \%$ to $211 \%$ of the energy demanded in the same building when a constructive solution of low U-value is implemented. The use of these high-quality solutions also reduces considerably the $\mathrm{CO}_{2}$ emissions, achieving values of $95 \%$ of reduction in the single-family house and $65 \%$ in the multi-family building. In addition, the use of constructive solutions with high thermal resistance enhances the energy rating of the housing units in all the cases.

However, the improvement of the energy efficiency of the buildings is also dependent on the type of building considered (single-family or multi-family) and the climatic zone. Single-family houses get larger benefits from the use of highquality materials in the envelope because of having more surface of envelope per $\mathrm{m}^{2}$ of building surface. In addition, buildings located in warm climatic zones are those that in general terms have a lower energy demand with any of the constructive solutions studied.

\section{Acknowledgement}

This research is funded by the Spanish Ministry of Economy and Competitiveness (Research Project TEC2012-38883-C02-02).

\section{References}

[1] European Parliament and of the Council, Directive 2002/91/EC of the European Parliament and of the Council of 16 December on the energy performance of buildings. DOUE 1, pp. 65-71, 2003.

[2] European Parliament and of the Council, Directive 2010/31/EU of the European Parliament and of the Council of 19 May on the energy performance of buildings. DOUE 153, pp. 13-35, 2010.

[3] United Nations, Kyoto protocol to the United Nations framework convention on climate change. 1997.

[4] Carpio M, García-Maraver A, Ruiz DP, Martínez A, Zamorano M, Energy rating for green buildings in Europe. WIT Transactions on Ecology and the Environment, 190 volume 1, pp. 381-94, 2014.

[5] Friedman C, Becker N, Erell E, Energy retrofit of residential building envelopes in Israel: A cost-benefit analysis. Energy.

[6] Nagy Z, Rossi D, Hersberger C, Irigoyen SD, Miller C, Schlueter A, Balancing envelope and heating system parameters for zero emissions retrofit using building sensor data. Appl. Energy, 131, pp. 56-66, 2014.

[7] Güçyeter B, Günaydın HM, Optimization of an envelope retrofit strategy for an existing office building. Energy Build, 55, pp. 647-59, 2012. 
[8] Huang J, Lv H, Gao T, Feng W, Chen Y, Zhou T, Thermal properties optimization of envelope in energy-saving renovation of existing public buildings. Energy Build, 75, pp. 504-10, 2014.

[9] Wang E, Shen Z, Grosskopf K, Benchmarking energy performance of building envelopes through a selective residual-clustering approach using high dimensional dataset. Energy Build, 75, pp. 10-22, 2014.

[10] Pisello AL, Cotana F, Nicolini A, Buratti C, Effect of dynamic characteristics of building envelope on thermal-energy performance in winter conditions: In field experiment. Energy Build, 80, pp. 218-30, 2014.

[11] Fang Z, Li N, Li B, Luo G, Huang Y, The effect of building envelope insulation on cooling energy consumption in summer. Energy Build, 77, pp. 197-205, 2014.

[12] Ministerio de Fomento, Government of Spain, Actualización al Documento Básico DB-HE “Ahorro de Energía” del Código Técnico de la Edificación. Orden FOM/1635/2013, 219, pp. 67137-209, 2013.

[13] Ministerio de la Vivienda, Government of Spain, Código Técnico de la Edificación (CTE). Real Decreto 314/2006 de 17 de marzo, BOE 74, pp. 11816-31, 2006.

[14] Carpio M, Zamorano M, Costa M, Impact of using biomass boilers on the energy rating and $\mathrm{CO} 2$ emissions of Iberian Peninsula residential buildings. Energy Build, 66, pp. 732-44, 2013.

[15] Crawley DB, Hand JW, Kummert M, Griffith BT, Contrasting the capabilities of building energy performance simulation programs. Build Environ, 43, pp. 661-73, 2008.

[16] Asociación Técnica Española de Climatización y Refrigeración, Universidad de Valencia, CERMA.V. 2.2, www.atecyr.org, 2011. 